\title{
Functional relationship
} between photosynthetic leaf gas exchange in response to silicon application and water stress mitigation in sugarcane

\author{
Krishan K. Verma ${ }^{1 \dagger}$, Xiu-Peng Song ${ }^{1 \dagger}$, Chhedi Lal Verma ${ }^{2}$, Zhong-Liang Chen ${ }^{1,3}$, Vishnu D. Rajput ${ }^{4}$, \\ Kai-Chao Wu' ${ }^{1}$, Fen Liao', Gan-Lin Chen ${ }^{5}$ and Yang-Rui Li $i^{1,3^{*}}$
}

\begin{abstract}
Background: Water stress is one of the serious abiotic stresses that negatively influences the growth, development and production of sugarcane in arid and semi-arid regions. However, silicon (Si) has been applied as an alleviation strategy subjected to environmental stresses.

Methods: In this experiment, Si was applied as soil irrigation in sugarcane plants to understand the mitigation effect of Si against harmful impact of water stress on photosynthetic leaf gas exchange.

Results: In the present study we primarily revealed the consequences of low soil moisture content, which affect overall plant performance of sugarcane significantly. Silicon application reduced the adverse effects of water stress by improving the net photosynthetic assimilation rate $\left(A_{\text {net }}\right) 1.35-18.75 \%$, stomatal conductance to water vapour (gs) 3.26-21.57\% and rate of transpiration (E) 1.16-17.83\%. The mathematical models developed from the proposed hypothesis explained the functional relationships between photosynthetic responses of Si application and water stress mitigation.
\end{abstract}

Conclusions: Silicon application showed high ameliorative effects on photosynthetic responses of sugarcane to water stress and could be used for mitigating environmental stresses in other crops, too, in future.

Keywords: Photosynthetic leaf gas exchange, Bio-modelling, Silicon, Sugarcane, Water stress

\section{*Correspondence: liyr@gxaas.net}

${ }^{\dagger}$ Krishan K. Verma, Xiu-Peng Song have contributed equally to this work

${ }^{1}$ Key Laboratory of Sugarcane Biotechnology and Genetic Improvement (Guangxi), Ministry of Agriculture and Rural Affairs/ Guangxi Key

Laboratory of Sugarcane Genetic Improvement/ Sugarcane Research Institute, Guangxi Academy of Agricultural Sciences/ Sugarcane Research

Center, Chinese Academy of Agricultural Sciences, Nanning, 530007, Guangxi, China

Full list of author information is available at the end of the article

\section{Background}

Sugarcane (Saccharum spp. Hybrid) is a major $\mathrm{C}_{4}$ cash crop predominantly grown in arid and semi-arid areas and is an important agro-industrial crop used for various purposes, i.e. sugar and ethanol production. Nowadays, water deficit causes severe loss to sugarcane production to various countries located in arid and semi-arid zones $[1,2]$. The maximum growth temperature for the highest cane productivity is about $25-30{ }^{\circ} \mathrm{C}$ and low temperature $\left(15-12{ }^{\circ} \mathrm{C}\right)$ reduces the plant development, cane and biomass production [3, 4]. China is the third largest sugar producer after Brazil and India among the first 10

(C) The Author(s) 2021. This article is licensed under a Creative Commons Attribution 4.0 International License, which permits use, sharing, adaptation, distribution and reproduction in any medium or format, as long as you give appropriate credit to the original author(s) and the source, provide a link to the Creative Commons licence, and indicate if changes were made. The images or other third party material in this article are included in the article's Creative Commons licence, unless indicated otherwise in a credit line to the material. If material is not included in the article's Creative Commons licence and your intended use is not permitted by statutory regulation or exceeds the permitted use, you will need to obtain permission directly from the copyright holder. To view a copy of this licence, visit http://creativeco mmons.org/licenses/by/4.0/. The Creative Commons Public Domain Dedication waiver (http://creativecommons.org/publicdomain/ zero/1.0/) applies to the data made available in this article, unless otherwise stated in a credit line to the data. 
sugarcane producing countries in the globe [5]. Brazil is the largest sugarcane producer globally, and its production is mainly for ethanol and sugar productivity $[6,7]$. The use of ethanol from renewable sources is mainly useful to minimize greenhouse gas emissions and dependence on fossil fuels [8].

Water stress is one of the serious abiotic stresses, which inhibits plant growth, development and production in all over the globe $[9,10]$. It brings a broad range of morphological, physiological and metabolic disruptions in plants. It also accelerates the rate of leaf necrosis, chlorosis, senescence and reduce photosynthetic pigments, which in turn downregulates photosynthetic activities, leaf area-expansion, resulting in lower biomass and productivity and sometimes in total mortality of the crops [9, $11,12]$. Plants have evolved various mechanisms to counteract the negative effects of water-deficit and protect themselves against the detrimental effects of ROS over production. The most significant antioxidative defence mechanisms, comprised to enzymatic and non-enzymatic activities that effectively scavenge the ROS and maintain the proper balance within the cell activities [1, 13, 14].

Nevertheless, severe stress for a long time would bring serious losses and cells mortality may occur [14, 15]. Such circumstances necessitate advance alleviation technologies to protect water stress damage to the sugarcane productivity in the near future. Mitigation of various environmental stresses, newly developed technologies need to be discovered and applied. Nowadays, the main focus of agricultural practices is to enhance crop production, environmental stresses which occur unpredictably and cause the major loss to crop yield are not often considered. To solve this problem, newly low cost effective techniques will be useful for agro-farming systems.

Silicon ( $\mathrm{Si}$ ) has been found to have a significant potential application in agricultural crops [10,16-18]. In various crops, during environmental stresses, application of $\mathrm{Si}$ plays a significant role in plants are well recognized $[10,16,18-22]$. Silicon is the eighth most abundant element in the world and second most abundant in the earth crust following oxygen on the basis of mass (28.8\%) [17, 23]. Demonstration into the role of $\mathrm{Si}$ on plant tolerance to unfavourable environmental conditions [24] has updated our knowledge of the possible impacts of $\mathrm{Si}$ on plants at the molecular, physiological and ecological levels [25-27]. Reduction of oxidative damage via reduced ROS production and/ or enhanced level of antioxidative enzyme activities to play significant role in $\mathrm{Si}$-induced stress mitigation $[18,28-30]$.

Hence, the main objective of this study was to understand the mitigation strategy of different Si application for water stress tolerance in sugarcane, with a main focus on photosynthetic leaf gas exchange. Furthermore, we aimed to identify the appropriate concentration of Si that can improve and/ or maintain the photosynthetic capacity of sugarcane during water stress.

\section{Materials and Methods}

\section{Plant material and growth conditions}

The experiment was carried out in an open greenhouse of Sugarcane Research Institute, Guangxi Academy of Agricultural Sciences, Nanning, Guangxi, China $\left(22.49^{\circ} \mathrm{N}\right.$, $\left.108.18^{\circ} \mathrm{E}\right)$. Newly released drought tolerant sugarcane (Saccharum officinarum L.) cultivar Guitang 42 (GT 42) was selected. One bud cane setts were planted in the field according to the farmer's standard practices. After 30-days of sowing, germinated healthy plants were shifted in plastic pots (width $33 \mathrm{~cm}$ and height $30 \mathrm{~cm}$ ) filled with fertile soil. The physio-chemical parameters of the applied soil are presented in Table 1. Cultivar GT 42 was developed and provided by Sugarcane Research Institute, Guangxi Academy of Agricultural Sciences, Nanning, Guangxi, China. After transplanting, the seedlings were allowed to proper establish for sixty-days. During this period, seedlings were fertilized and disease management was carried out according to commercial cultivation practices. Throughout the normal growth period, plants were watered till the filled capacity to maintain the equal volume of soil moisture. To maintain adequate soil nutrient level, i.e. nitrogen $(\mathrm{N})$, potassium (P) and phosphorous (K) were applied to the soil at specific time period. The basal dose of fertilizer in soil as nitrogen ( $\mathrm{N}, 70 \mathrm{mg} \mathrm{kg}^{-1}$ soil), potassium (P, $50 \mathrm{mg} \mathrm{kg}{ }^{-1}$ soil) and phosphorous (K, $100 \mathrm{mg} \mathrm{kg}^{-1}$ soil) were applied in each pot. During the experiment, randomly uniform plants were selected for water stress (moderate, 55-50\% of soil moisture) and silicon application (0, 100, 200 and $500 \mathrm{mg} \mathrm{L}^{-1}$ ), applied as soil irrigation. The $\mathrm{Si}$ solution was freshly prepared in running tap water. The Si solution was applied once in 1 month upto 4 months (treatment frequency @ 4). Calcium metasilicate $\left(\mathrm{CaO} . \mathrm{SiO}_{2}\right)$ was used as a source of Si. The water-stressed plants were selected as control (without $\mathrm{Si}$ ) in the whole experiment. The soil moisture (\%) was observed by Soil Moisture Meter at regular basis. The atmospheric variables such as ambient air temperature $\left({ }^{\circ} \mathrm{C}\right)$, air relative humidity (\%) and sunshine $(\mathrm{h})$ were recorded throughout the study (Table 2).

\section{Leaf gas exchange measurements}

The leaf gas exchange was measured on the 30, 60, 90 and 120 days after water stress with and without Si application $\left(0,100,200\right.$ and $\left.500 \mathrm{mg} \mathrm{L}^{-1}\right)$. Net photosynthetic 


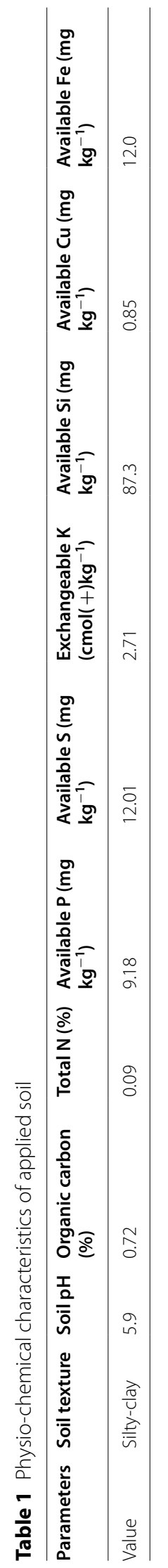


Table 2 Atmospheric variable during experiment

\begin{tabular}{|c|c|c|c|c|c|c|c|c|}
\hline & & March & April & May & June & July & August & September \\
\hline $\begin{array}{l}\text { Ambient air } \\
\text { temperature } \\
\left({ }^{\circ} \mathrm{C}\right)\end{array}$ & Maximum & 25.5 & 27.6 & 30.4 & 32.1 & 32.9 & 32.7 & 31.6 \\
\hline Minimum & & 15.0 & 19.6 & 22.8 & 24.9 & 25.4 & 25.2 & 23.6 \\
\hline Mean & & 20.3 & 23.6 & 26.6 & 28.5 & 29.2 & 29.0 & 27.6 \\
\hline $\begin{array}{l}\text { Ambient air } \\
\text { humidity (\%) }\end{array}$ & Mean & 82 & 81 & 80 & 82 & 82 & 78 & 75 \\
\hline Sunshine (h) & Mean & 12 & 12.7 & 13.2 & 13.5 & 13.4 & 12.9 & 12.3 \\
\hline
\end{tabular}

assimilation rate $\left(A_{\text {net }}\right)$, stomatal conductance to water vapor (gs) and rate of transpiration (E) were observed by portable photosynthesis system (LI-6800, LI-COR Biosciences, Lincoln, NE, USA) from photosynthetically fully mature leaves (leaf +1$)$. From each treatment, a minimum of five $(n=5)$ measurements were recorded between 9:00 and 11:30 h. Photosynthetic active radiation (PAR), temperature and $\mathrm{CO}_{2}$ concentration was adjusted to $1200 \mu \mathrm{mol} \mathrm{m}^{-2} \mathrm{~s}^{-1}, 25^{\circ} \mathrm{C}$ and $400 \mathrm{ppm}$ in the leaf chamber while observing photosynthetic capacity.

\section{Bio-modelling of net photosynthetic assimilation rate, stomatal conductance and transpiration rate in response to silicon application for water stress mitigation}

Hypothesis-I Rate of change of physiological response $\left(A_{\text {net }}\right.$, gs and $\left.\mathrm{E}\right)$ with respect to silicon application $\left(\mathrm{dPs}_{\mathrm{i}} /\right.$ $\mathrm{dSi}$ ) is directly proportional to the appropriated physiological response rate against silicon dose. Mathematically it can be expressed as below.

$$
\frac{d P S i}{d S i} \propto \frac{P-\alpha}{\beta}
$$

$P_{\mathrm{Si}}=$ physiological response rate against applied doze of silicon.

$\alpha, \beta=$ appropriation constants.

Instead of minus sign in Eq. 1 positive sign could be also used.

Equation 1 Can be also written as below after introducing a proportionality constant $(\gamma)$

$$
\frac{d P S i}{d S i}=\gamma \frac{P-\alpha}{\beta}
$$

Above equation is a governing equation and can be solved by separating variables as under

$$
\frac{d P S i}{\frac{P-\alpha}{\beta}}=-\gamma d S i
$$

Minus sign shows the decreasing physiological response against increased stress level. Equation 3 can be rewritten by introducing new constant $a=1 / \beta$, and $\mathrm{b}=\alpha / \beta$ as below

$$
\int \frac{d P S i}{a P-b}=-\gamma \int d S i
$$

General solution of Eq. 4 can be obtained as below

$$
\begin{aligned}
& \frac{1}{\alpha} \ln (a P-b)=-\gamma S i \\
& \ln (a P-b)=-\alpha \gamma S i
\end{aligned}
$$

If $\lambda=a \gamma$, above Eq. 6 reduces to

$$
\ln (a P s i-b)=-\lambda S i
$$

$P_{\mathrm{Si}}$ is physiological response against silica dose of $\mathrm{S}$

$$
\begin{aligned}
& (a P s i-b)=e^{-\lambda S i} \\
& P_{S i}=\frac{b}{a}+\frac{1}{a} e^{-\lambda S i} \\
& P s i=\mu+\sigma e^{-\lambda S i} \\
& P s i=\sigma\left(\rho+e^{-\lambda S i}\right)
\end{aligned}
$$

where, $\rho=\mu / \sigma$. 


\section{Variations of photosynthetic response rate $\left(P_{t}\right)$, stomatal conductance and transpiration rate as a function of time $(T)$ under silicon application for water stress mitigation}

\section{Hypothesis-II}

1. The rate of change of physiological responses (P) with respect to time $(\mathrm{T})$, i.e. $(\mathrm{dP} / \mathrm{dT})$ is directly proportional to the expected maximum physiological response rate $(\mathrm{Pm})$ under a given situation. Mathematically it can be written as below

$$
\frac{d P}{d T} \propto P_{m}
$$

2. Rate of change of physiological response $(\mathrm{P})$ with respect to time $(\mathrm{T})$ i.e. $(\mathrm{dP} / \mathrm{dT})$ is also directly proportional to the expected difference between expected maximum physiological response rate and present physiological response rate under a given conditions and can be written as below

$$
\frac{d P}{d T} \propto\left(P_{m}-P\right)
$$

Combining hypotheses 12 and 13, a general hypothesis can be written as below

$$
\frac{d P}{d T} \propto P_{m}\left(P_{m}-P\right)
$$

Introducing a proportionality constant $\zeta$ in Eq. 3 one will arrive at following governing equation

$$
\frac{d P}{d T}=\zeta P_{m}\left(P_{m}-P\right)
$$

Separating the variables and integrating,

$$
\int \frac{d P}{\left(P_{m}-P\right)}=\tau \int d T
$$

where $\tau=\zeta$. $P_{m}$, a new constant.

Integrating Eq. 16 one will obtain the following solution

$$
-\ln \left(P_{m}-P\right)=\tau T+I
$$

Which can be simplified as below

$$
P=P_{m}-C e^{-\tau T}
$$

where $\mathrm{C}=\mathrm{e}^{\mathrm{I}}$ and can be worked out by substituting initial conditions as $\mathrm{T}=0, \mathrm{P}=0$ as below

$$
0=P_{m}-C e^{-\tau \times 0}
$$

$$
C=P_{m}
$$

A generalized solution can be written as below

$$
P_{t}=P_{m}\left(1-e^{-\tau T}\right)
$$

\section{Statistical analyses}

Statistical analyses were performed on physiological responses to silicon and water stress condition, depending on observations using CurveExpert 1.4 software.

\section{Results}

Photosynthetic leaf gas exchange is the major process for all metabolic processes in plants. After soil irrigation of Si solution for 30, 60, 90 and 120 days, the net photosynthetic assimilation rate $\left(A_{\text {net }}\right)$, stomatal conductance to water vapor (gs) and rate of transpiration (E) were determined. It is clear from Fig. 1a-h, which showed significantly different between water stress (no $\mathrm{Si})$ and $\mathrm{Si}\left(100,200\right.$ and $\left.500 \mathrm{mg} \mathrm{L}^{-1}\right)$ at specific time intervals. The results showed that the $A_{\text {net }}$ of sugarcane leaves was significantly enhanced by $1.35-18.70 \%$ by low to high $\mathrm{Si}$ concentrations, respectively, compared to the water-stressed plants (Fig. 1). The highest (\%) gain was found in $A_{\text {net }}$ of $500 \mathrm{mg} \mathrm{L}^{-1} \mathrm{Si}$ (14.99-18.70\%) as compare to 100 and $200 \mathrm{mg} \mathrm{L}^{-1} \mathrm{Si}$ at 30, 60, 90 and 120 days after $\mathrm{Si}$ application (Fig. $1 \mathrm{e}-\mathrm{h}$ ). On the other hand, the $A_{\text {net }}$ was found maximum (4.97 and $18.70 \%$ ) at 120 days (Fig. $1 \mathrm{~b}$ and $\mathrm{d}$ ) except Fig. 1c.

Figure 2 showed that the low to high concentrations of Si (100 to $500 \mathrm{mg} \mathrm{L}^{-1}$ ) significantly enhanced gs of the sugarcane leaves by $3.26-21.57 \%$ (Fig. $2 \mathrm{~b}-\mathrm{h}$ ) as compared to the stressed plants (no $\mathrm{Si}$ ), respectively. Silicon enhanced the gs activity and improved and/or maintained biomass productivity. The highest (\%) gain (13.48$21.57 \%$ ) was found in $500 \mathrm{mg} \mathrm{L}^{-1} \mathrm{Si}$ dose as compare to the lowest concentration (Fig. $2 \mathrm{e}-\mathrm{h}$ ). On the other hand the maximum (\%) gain was noticed in (11.76 and $21.57 \%)$ at 30 days (200 and $500 \mathrm{mg} \mathrm{L}^{-1}$ ) as compare to 60,90 and 120 days after Si application (Fig. 2b-d). After soil irrigation of Si for specific time intervals, i.e. 30, 60, 90 and 120 days, the rate of transpiration was observed on the photosynthetically mature leaves of sugarcane (Fig. 3bh). The results showed that the higher dose of $\mathrm{Si}(500 \mathrm{mg}$ $\mathrm{L}^{-1}$ ) significantly enhanced the E response (8.14-17.83\%) as compared to the stressed plants, respectively (Fig. 3). As shown in Fig. 3b-d, the E was found the highest (3.88, 7.75 and $17.83 \%)$ at 120 days after $\mathrm{Si}$ application as compared to 30, 60 and 90 days after water stress (Fig. 3b-d).

The data of $A_{\text {net }}$ gs and E fit well within the derived equation, and their respective values of ' $r$ ' were observed 

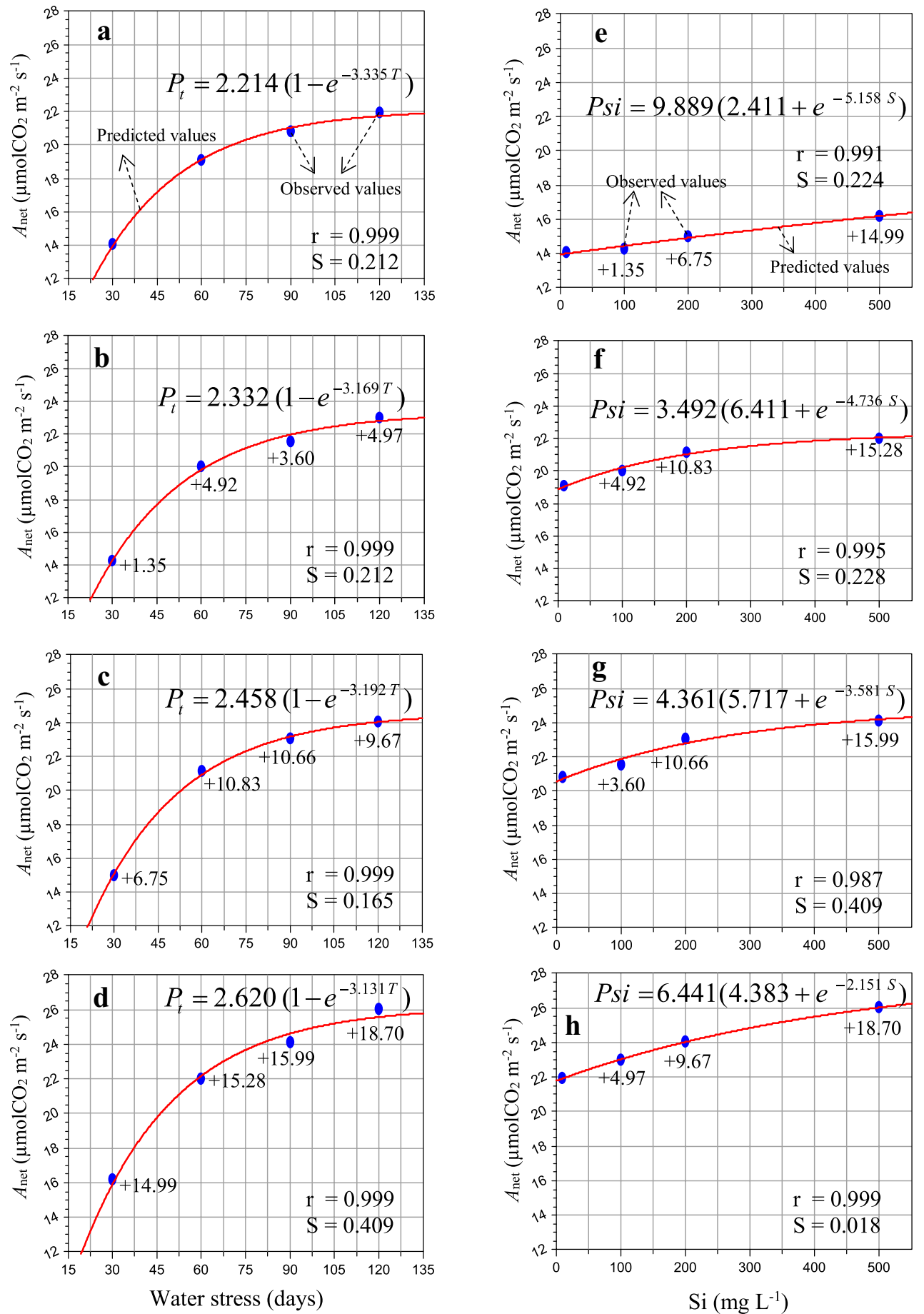

Fig. 1 The change of net photosynthetic assimilation rate $\left(A_{\text {net }}-\mu \mathrm{mol} \mathrm{CO} \mathrm{Cm}^{-2} \mathrm{~s}^{-1}\right)$ to water stress condition (55-50\% soil moisture, moderate, a-d) and different silicon levels (e-h) in sugarcane (Saccharum officinarum L. cv. GT 42) plants. Average mean values are each point $(n=5)$. Blue ovals denote the actual values and red lines show the predicted values. Parenthesis values indicate $(+)$ percent gain. $S=$ standard error and $r=$ correlation coefficient 

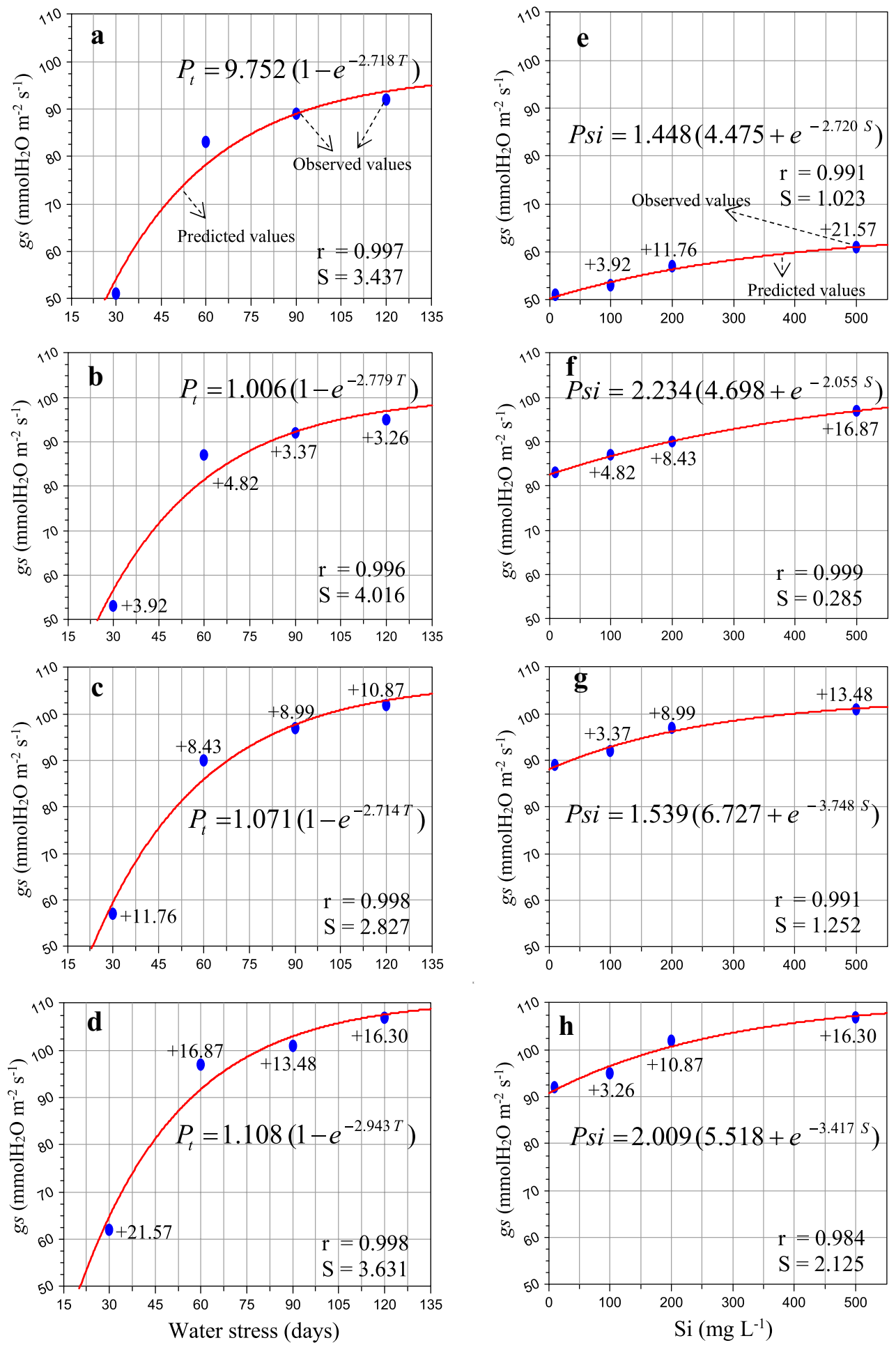

Fig. 2 Response of stomatal conductance to water vapor ( $\mathrm{gs}-\mathrm{mmol} \mathrm{H} \mathrm{O} \mathrm{m}^{-2} \mathrm{~s}^{-1}$ ) to water stress condition (55-50\% soil moisture, moderate,a-d) and different silicon levels (e-h) in sugarcane (Saccharum officinarum L. cv. GT 42) plants. Average mean values are each point ( $n=5$ ). Blue ovals

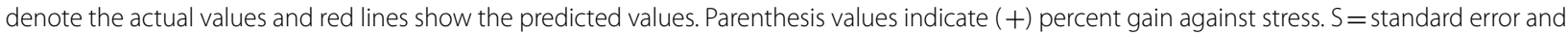
$r=$ correlation coefficient 

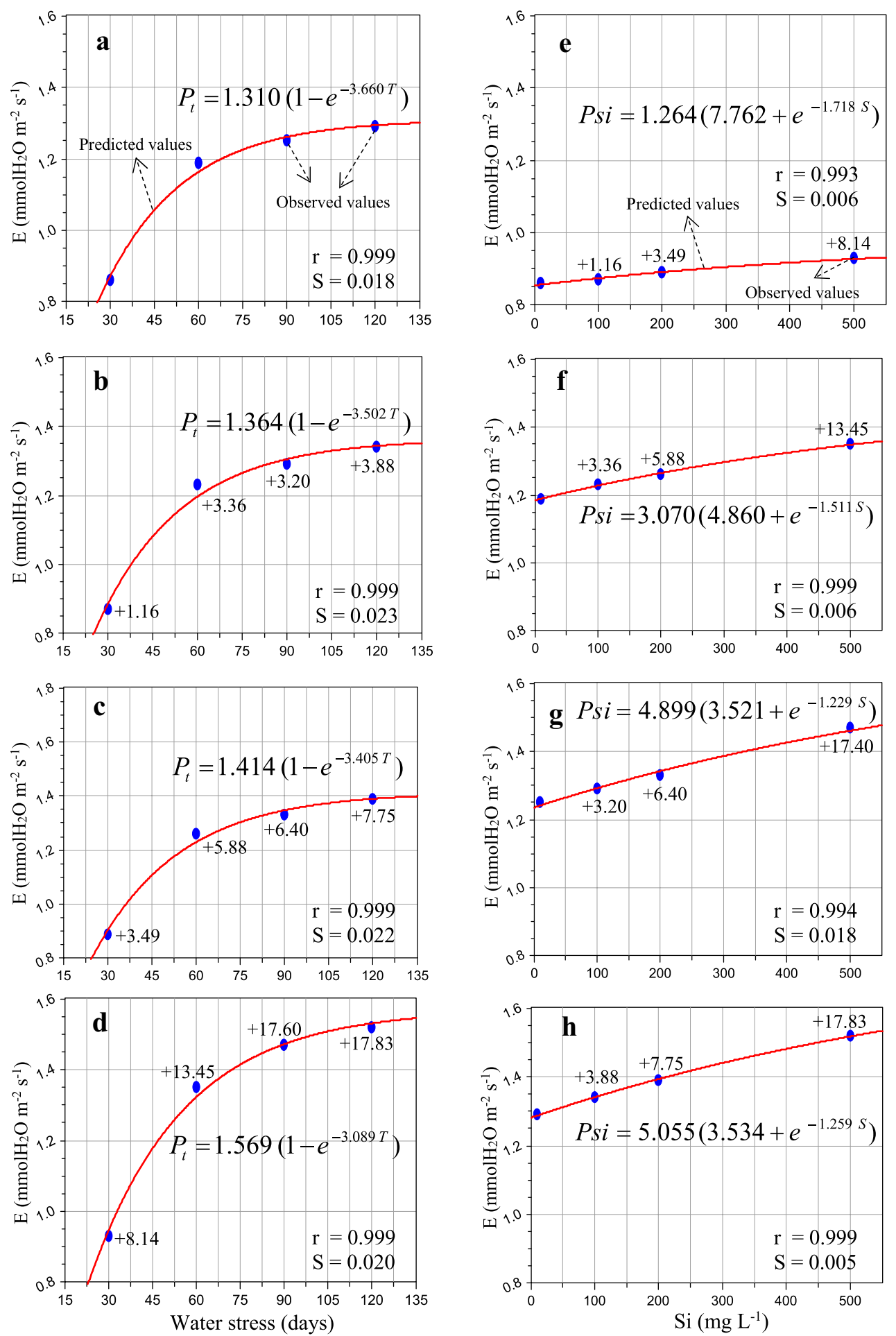

Fig. 3 Effect of water stress $\mathbf{a}-\mathbf{d})$ and different silicon levels $(\mathbf{e}-\mathbf{h})$ on the rate of transpiration $\left(\mathrm{mmol} \mathrm{H}_{2} \mathrm{O} \mathrm{m}^{-2} \mathrm{~s}^{-1}\right)$ in sugarcane (Saccharum officinarum L. CV. GT 42) plants. Average mean values are each point $(n=5)$. Blue ovals denote the actual values and red lines show the predicted values. Parenthesis values indicate $(+)$ percent gain against stress. $S=$ standard error and $r=$ correlation coefficient 
to be in the range of $0.999-0.999,0.996-0.998$ and $0.999-0.999$ and 'S' $0.165-0.409,2.827-4.016$ and $0.018-$ 0.023 for water stress condition (Table 3). The $A_{\text {net, }}$ gs and $\mathrm{E}$ also fit well in the derived hypothesis equation with ' $r$ ' values ranging from 0.987 to $0.999,0.984-0.999$ and $0.993-0.999$ and ' $S$ ' ranging from 0.018 to $0.409,0.285-$ $2.125,0.005-0.018$ for various levels of $\mathrm{Si}$ application (Table 4). The hypotheses were validated and developed models tested well with field observations.

\section{Discussion}

Photosynthetic leaf gas exchange is the main source of all metabolic processes and biomass production in plants $[2,31]$. Chlorophyll is an important pigment associated in photosynthetic capacity and plays a vital role in the absorption and transmission of light energy [10, 32]. Insufficient water causes a major loss in plant leaf areaexpansion, photosynthetic pigments, which undeniably impairs and decrease photosynthetic $\mathrm{CO}_{2}$ assimilation rate, directly involved in plant growth and development $[16,18,33]$. Exogenous application of Si preserves photosynthetic pigments and a result increased and/ or improved photosynthetic performance in the plants cultivated during unfavourable environmental conditions $[10,14,17,18]$. The present observations showed that the application of Si mitigates the harmful effects of waterdeficit and enhanced the leaf canopy, leaf chlorophyll index in comparison to without $\mathrm{Si}$ under stress condition (Figs. 1, 2, 3). Similar findings are confirmed by the previous demonstrations of Farooq and Dietz [17], Shi et al. [14], Frew et al. [18], Verma et al. [2, 10].

For the water-stressed plants, stomatal closure is one of the first plant response to reduce loss of water, accompanied by a remarkable loss in gs and consequently, stomatal limitation of $A_{\text {net }}[10,11]$. The impact of Si on leaf photosynthetic responses were highly dose-dependent (Figs. 1, 2, 3). Nevertheless, the application of $\mathrm{Si}$ also resulted in an enhancement on the rate of transpiration, possibly driven by the increased gs activity to maintain a steady state of photosynthetic $\mathrm{CO}_{2}$ assimilation rate subjected to water-stressed plants. Different relevant mechanisms linked with stress mitigation in higher plants have been noticed: enhanced untrastructural reinforcement [34], altered photosynthesis [12, 35, 36] and changes in gs activity [14, 37]. In the present study, the rate of transpiration in sugarcane leaves were enhanced by addition of $\mathrm{Si}$ subjected to limited water irrigation (Fig. 3b-h). Similar findings are in accordance with those measured in Triticum aestivum, Sorghum bicolour, Oryza sativa and Solanum lycopersicum [14, 37-39]. These findings suggest that the impact of Si on photosynthetic leaf gas exchange may be associated to plant families, varieties and duration of stress.
Table 3 Model constants of net photosynthetic assimilation rate $\left(A_{\text {net }}\right)$, stomatal conductance to water vapour (gs) and rate of transpiration (E) subjected to water stress condition and $\mathrm{Si}$ application

\begin{tabular}{lcllll}
\hline $\begin{array}{l}\text { Photosynthetic } \\
\text { response }\end{array}$ & Stress (days) & Pm & $\mathbf{\tau}$ & $\mathbf{r}$ & $\mathbf{S}$ \\
\hline$A_{\text {net }}$ & 30 & 2.214 & 3.335 & 0.999 & 0.212 \\
& 60 & 2.332 & 3.169 & 0.999 & 0.289 \\
& 90 & 2.458 & 3.192 & 0.999 & 0.165 \\
& 120 & 2.620 & 3.131 & 0.999 & 0.409 \\
gs & 30 & 9.752 & 2.718 & 0.997 & 3.437 \\
& 60 & 1.006 & 2.779 & 0.996 & 4.016 \\
& 90 & 1.071 & 2.714 & 0.998 & 2.827 \\
& 120 & 1.108 & 2.943 & 0.998 & 3.631 \\
E & 30 & 1.310 & 3.660 & 0.999 & 0.018 \\
& 60 & 1.364 & 3.502 & 0.999 & 0.023 \\
& 90 & 1.414 & 3.405 & 0.999 & 0.022 \\
& 120 & 1.569 & 3.089 & 0.999 & 0.020 \\
\hline
\end{tabular}

$P m$ and $\tau$ Model constants, $r$ Correlation coefficient, $S$ Standard error, and 30, 60, 90 and 120 indicates days of stress

\section{Significance of bio-model hypothesis}

The correlation coefficients ( $r$ ) for each set of data such as $A_{\text {net, }}$ gs and $\mathrm{E}$ with and without $\mathrm{Si}$ application with water stress condition were found in the range of 0.984-0.999 (Tables 3 and 4). This means that the derived equation model explains the changes in photosynthetic capacity subjected to stress condition with various levels of $\mathrm{Si}$ and time perfectly well. Instrumental and human errors all together are within $2 \%$ limit. The developed models explain the rate of change of physiological responses with respect to $\mathrm{Si}$ application and time (stress duration) precisely. This may be directly proportional to the appropriate physiological responses against $\mathrm{Si}$ application for predicting the gains (\%) of other plants in similar conditions, which can also be verified. The developed models may be useful to understand the nature of changes in major physiological response rates with respect to silicon applications and time.

\section{Conclusion}

The results of the present study clearly demonstrated the capacity of different levels of Si to ameliorate the tolerance to water-deficit condition. The exogenous application of Si showed potential results by increasing photosynthetic leaf gas exchange activities and improving plant biomass. The present experiment demonstrates the appropriate concentration of $\mathrm{Si}$ can be applied to alleviate the harmful effects of water-stressed in sugarcane plants. 
Table 4 Model constants of net photosynthetic assimilation rate $\left(A_{\text {net }}\right)$, stomatal conductance to water vapour (gs) and rate of transpiration (E) to Si application

\begin{tabular}{|c|c|c|c|c|c|c|}
\hline Photosynthetic response & Silicon $\left(\mathrm{mg} \mathrm{L}^{-1}\right)$ & $\sigma$ & $\rho$ & $\kappa$ & $r$ & $S$ \\
\hline \multirow[t]{4}{*}{$A_{\text {net }}$} & 0 & 9.889 & 2.411 & 5.158 & 0.991 & 0.224 \\
\hline & 100 & 3.492 & 6.411 & 4.736 & 0.995 & 0.228 \\
\hline & 200 & 4.361 & 5.717 & 3.581 & 0.987 & 0.409 \\
\hline & 500 & 6.441 & 4.383 & 2.151 & 0.999 & 0.018 \\
\hline \multirow[t]{4}{*}{ gs } & 0 & 1.448 & 4.475 & 2.720 & 0.991 & 1.023 \\
\hline & 100 & 2.234 & 4.698 & 2.055 & 0.999 & 0.285 \\
\hline & 200 & 1.539 & 6.727 & 3.748 & 0.991 & 1.252 \\
\hline & 500 & 2.009 & 5.518 & 3.417 & 0.984 & 2.125 \\
\hline \multirow[t]{4}{*}{ E } & 0 & 1.264 & 7.762 & 1.718 & 0.993 & 0.006 \\
\hline & 100 & 3.070 & 4.860 & 1.511 & 0.999 & 0.006 \\
\hline & 200 & 4.899 & 3.521 & 1.229 & 0.994 & 0.018 \\
\hline & 500 & 5.055 & 3.534 & 1.259 & 0.999 & 0.005 \\
\hline
\end{tabular}

$\sigma, \rho$ and $\kappa$ model constants, $r$ Correlation coefficient, $S$ Standard error, and $0,100,200$ and $500 \mathrm{mg} \mathrm{L}^{-1}$ indicates Si concentration

\section{Abbreviations}

$A_{\text {net }}$ : Net photosynthetic assimilation rate; Gs: Stomatal conductance to water vapour; E: Rate of transpiration; PAR: Photosynthetic active radiation; Si: Silicon.

\section{Acknowledgements}

We are thankful to the Guangxi Academy of Agricultural Sciences, Nanning, Guangxi, China for providing the necessary facilities for this study.

\section{Authors' contributions}

KKV and XPS conceptualization, methodology, software, validation, investigation, data processing, writing - original draft; CLV data curation, statistical biomodeling interpretation and validation; ZLC and KCW methodology, formal analysis and data processing; VDR software and writing-review and editing; FL and GLC writing-review and editing; YRL conceptualization, methodology, investigation, writing - review and editing, project administration and funding acquisition. All authors read and approved the final manuscript.

\section{Funding}

This study was financially supported by the Youth Program of National Natural Science Foundation of China (31901594), Fund for Guangxi Innovation Teams of Modern Agriculture Technology (gjnytxgxcxtd-03-01), Fund of Guangxi Academy of Agricultural Sciences (2021YT011) and Guangxi R and D Program Fund (GK17195100).

\section{Availability of data and materials}

Not available.

\section{Declarations}

Ethics approval and consent to participate Not applicable.

\section{Consent for publication}

Not applicable.

\section{Competing interests}

The authors declare that they have no competing interests.

\section{Author details}

${ }^{1}$ Key Laboratory of Sugarcane Biotechnology and Genetic Improvement (Guangxi), Ministry of Agriculture and Rural Affairs/ Guangxi Key Laboratory of Sugarcane Genetic Improvement/ Sugarcane Research Institute, Guangxi Academy of Agricultural Sciences/ Sugarcane Research Center, Chinese
Academy of Agricultural Sciences, Nanning, 530007, Guangxi, China. ${ }^{2}$ Irrigation and Drainage Engineering, ICAR-Central Soil Salinity Research Institute, Regional Research Station, Lucknow 226005, India. ${ }^{3}$ College of Agriculture, Guangxi University, Nanning 530004, Guangxi, China. ${ }^{4}$ Academy of Biology and Biotechnology, Southern Federal University, Rostov-on-Don 344090,

Russia. ${ }^{5}$ Institute of Biotechnology, Guangxi Academy of Agricultural Sciences, Nanning 530 007, Guangxi, China.

Received: 6 March 2021 Accepted: 19 April 2021

Published online: 01 May 2021

\section{References}

1. Verma KK, Liu XH, Wu KC, Singh RK, Song QQ, Malviya MK, Song XP, Singh P, Verma CL, Li YR. The impact of silicon on photosynthetic and biochemical responses of sugarcane under different soil moisture levels. SILICON. 2020:12:1355-67.

2. Verma KK, Song XP, Verma CL, Malviya MK, Guo DJ, Rajput VD, Sharma A, Wei KJ, Chen GL, Solomon S, Li YR. Predication of photosynthetic leaf gas exchange of sugarcane (Saccharum spp.) leaves in response to leaf positions to foliar spray of potassium salt of active phosphorus under limited water irrigation. ACS Omega. 2021;6:2396-409.

3. Li YR, Yang LT. Sugarcane industry in China. Sugar Tech. 2015;17:1-8

4. Elsheery NI, Sunoj VSJ, Wen Y, Zhu JJ, Muralidharan G, Cao KF. Foliar application of nanoparticles mitigates the chilling effect on photosynthesis and photoprotection in sugarcane. Plant Physiol Biochem. 2020;149:50-60.

5. Chen GL, Zheng FJ, Lin B, Lao SB, He J, Huang Z, Zeng Y, Sun J, Verma KK. Phenolic and volatile compounds in the production of sugarcane vinegar. ACS Omega. 2020;5:30587-95.

6. Goldemberg L. The Brazalian biofuels industry. Biotechnol Biofuels. 2008;1:1-7.

7. Martins MTBM, de Souza WR, da Cunha BADB, Basso MF, de Oliveira NG, Vinecky F, Martins PK, de Oliveira PA, Arenque-Musa BC, de Souza AP, Buckeridge MS, Kobayashi AK, Quirino BF, Molinari HBC. Characterization of sugarcane (Saccharum spp.) leaf senescence: implications for biofuel production. Biotechnol Biofuels. 2016;9:153. https://doi.org/10.1186/ s13068-016-0568-0.

8. Savage N. Fuel options: the ideal biofuel. Nature. 2011:474:S9-11.

9. Dinh TH, Watanabe K, Takaragawa H, Nakabaru M, Kawamitsu Y. Photosynthetic response and nitrogen use efficiency of sugarcane under drought stress conditions with different nitrogen application levels. Plant Prod Sci. 2017:20:412-22. 
10. Verma KK, Singh P, Song XP, Malviya MK, Singh RK, Chen GL, Solomon S, Li YR. Mitigating climate change for sugarcane improvement: role of silicon in alleviating abiotic stresses. Sugar Tech. 2020;22:741-9.

11. Liu HX, Guo ZG. Forage yield and water use efficiency of alfalfa applied with silicon under water deficit conditions. Philipp Agric Sci. 2013;96:370-6.

12. Verma KK, Wu KC, Verma CL, Li DM, Malviya MK, Singh RK, Singh $P$, Chen GL, Song XP, Li YR. Developing mathematical model for diurnal dynamics of photosynthesis in Saccharum officinarum responsive to different irrigation and silicon application. PeerJ. 2020;8:e10154. https://doi.org/10. 7717/peerj.10154.

13. Meloni DA, Oliva MA, Martinez CA, Cambraia J. Photosynthesis and activity of superoxide dismutase, peroxidase and glutathione reductase in cotton under salt stress. Environ Exp Bot. 2003;49:69-76.

14. Shi Y, Zhang Y, Han W, Feng R, Hu Y, Guo J, Gong H. Silicon enhances water stress tolerance by improving root hydraulic conductance in Solanum lycopersicum L. Front Plant Sci. 2016;7:196. https://doi.org/10.3389/ fpls.2016.00196

15. Turk H, Erdal S, Genisel M, Atici O, Demir Y, Yanmis D. The regulatory effect of melatonin on physiological, biochemical and molecular parameters in cold-stressed wheat seedlings. Plant Growth Regul. 2014;74:139-52.

16. Savvas D, Ntatsi G. Biostimulant activity of silicon in horticulture. Sci Hortic. 2015;196:66-81.

17. Farooq MA, Dietz KJ. Silicon as versatile player in plant and human biology: overlooked and poorly understood. Front Plant Sci. 2015;6:994. https://doi.org/10.3389/fpls.2015.00994.

18. Frew A, Weston LA, Reynolds OL, Gurr GM. The role of silicon in plant biology: a paradigm shift in research approach. Ann Bot. 2018;121:1265-73.

19. Epstein E. Silicon: its manifold roles in plants. Ann Appl Biol. 2009;155:155-60.

20. Guntzer F, Keller C, Meunier JD. Benefits of plant silicon for crops: a review. Agron Sustain Dev. 2012;32:201-13.

21. Zhu Y, Gong H. Beneficial effects of silicon on salt and drought tolerance in plants. Agron Sustain Dev. 2014;34:455-72.

22. Debona D, Rodrigues FA, Datnoff $L E$. Silicon's role in abiotic and biotic plant stresses. Annu Rev Phytopathol. 2017;55:85-107.

23. Epstein E. Silicon. Annu Rev Plant Biol. 1999;50:641-64.

24. Cooke J, Leishman MR. Consistent alleviation of abiotic stress with silicon addition: a meta-analysis. Funct Ecol. 2016;30:1340-57.

25. Detmann KC, Araújo WL, Martins SCV, Sanglard LMVP, Reis JV, Detmann E, Rodrigues FA, Nunes-Nesi A, Fernie AR, DaMatta FM. Silicon nutrition increases grain yield, which, in turn, exerts a feed-forward stimulation of photosynthetic rates via enhanced mesophyll conductance and alters primary metabolism in rice. New Phytol. 2012;196:752-62.

26. Ma JF, Yamaji N. A cooperative system of silicon transport in plants. Trends Plant Sci. 2015;20:435-42.
27. Cooke J, DeGabriel JL, Hartley SE. The functional ecology of plant silicon: geoscience to genes. Funct Ecol. 2016;30:1270-6.

28. Zhu Z, Wei G, Li J, Qian Q, Yu J. Silicon alleviates salt stress and increases antioxidant enzymes activity in leaves of salt-stressed cucumber (Cucumis sativus L.). Plant Sci. 2004;167:527-33.

29. Ali A, UI Haq T, Mahmood R, Jaan M, Abbas MN. Stimulating the antioxidative role and wheat growth improvement through silicon under salt stress. SILICON. 2019;11:2403-6.

30. Kim YH, Khan AL, Waqas M, Lee IJ. Silicon regulates antioxidant activities of crop plants under abiotic-induced oxidative stress: a review. Front Plant Sci. 2017. https://doi.org/10.3389/fpls.2017.00510.

31. Lu L, Huang M, Huang Y, Corvini PFX, Ji R, Zhao L. $\mathrm{Mn}_{3} \mathrm{O}_{4}$ nanozymes boost endogenous antioxidant metabolities in cucumber (Cucumis sativus ) plant and enhance resistance to salinity stress. Environ Sci Nano. 2020;7:1692-703.

32. Arnao MB, Hernández-Ruiz J. Protective effect of melatonin against chlorophyll degradation during the senescence of barley leaves. J Pineal Res. 2009:46:58-63.

33. Muller O, Cohu CM, Stewart JJ, Protheroe JA, Demmigadams B, Adams WW. Association between photosynthesis and contrasting features of minor veins in leaves of summer annuals loading phloem via symplastic versus apoplastic routes. Physiol Plant. 2014;152:174-83.

34. Meunier JD, Barboni D, Anwar-ul-Haq M, Levard C, Chaurand R, Vidal V, Grauby O, Huc R, Laffont-Schwob I, Rabier J, Keller C. Effect of phytoliths for mitigating water stress in durum wheat. New Phytol. 2017;215:229-39.

35. Rahman A, Wallis CM, Uddin W. Silicon-induced systemic defense responses in perennially egg grass against infection by Magnaporthe oryzae. Phytopathol. 2015;105:748-57.

36. Kang J, Zhao W, Zhu X. Silicon improves photosynthesis and strengthens enzyme activities in the $C_{3}$ succulent xerophyte Zygophyllum xanthoxylum under drought stress. J Plant Physiol. 2016;199:76-86.

37. Hattori T, Inanaga S, Araki H, An P, Morita S, Luxová M, Lux A. Application of silicon enhanced drought tolerance in Sorghum bicolor. Physiol Plant. 2005;123:459-66.

38. Gong HJ, Zhu XY, Chen KM, Wang SM, Zhang CL. Silicon alleviates oxidative damage of wheat plants in pots under drought. Plant Sci. 2005;169:313-21.

39. Chen W, Yao XQ, Cai KZ, Chen J. Silicon alleviates drought stress of rice plants by improving plant water status, photosynthesis and mineral nutrient absorption. Biol Trace Elem Res. 2011;142:67-76.

\section{Publisher's Note}

Springer Nature remains neutral with regard to jurisdictional claims in published maps and institutional affiliations.
Ready to submit your research? Choose BMC and benefit from:

- fast, convenient online submission

- thorough peer review by experienced researchers in your field

- rapid publication on acceptance

- support for research data, including large and complex data types

- gold Open Access which fosters wider collaboration and increased citations

- maximum visibility for your research: over 100M website views per year

At BMC, research is always in progress.

Learn more biomedcentral.com/submissions 